\title{
Authenticity and Learning: Implications for Reference Librarianship and Information Literacy Instruction
}

\section{Kevin Michael Klipfel}

\begin{abstract}
This article articulates and defends a student-centered approach to reference and instructional librarianship defined by authentic engagement with students' interests. A review of the history of the construct of authenticity in philosophy, humanistic and existential psychology, and contemporary educational psychology is traced. Connections are drawn between the philosophy of authentic engagement and the tradition in librarianship of "Counselor Librarianship." Recommendations for applications to the library context are then outlined.
\end{abstract}

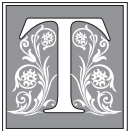

he construct of authenticity has been directly tied to human well-being and increased meaning in life at least since the Ancient Greek philosophers began to ask Socrates' question - "How should one live" - over two thousand years ago. ${ }^{1}$ Indeed, for Greek moralists such as Aristotle, the flourishing human life was a self-actualized one, in which an individual performs actions that reflect one's true calling as a human being. ${ }^{2}$ In this picture of the good life, authentic activities "do not have happiness or pleasure as their desired end; instead, pleasure is a consequence of a life in which one successfully manages to perform these activities well." ${ }^{3}$ Thus, in these theories, an authentic life is taken to be fundamental. It is the core component of human flourishing and the basis from which all other goods derive.

The primacy of authenticity's role for human happiness was later, in the 19th century, promulgated by proto-existential philosophers such as Kierkegaard and Nietzsche, and then further developed by 20th-century existentialists such as Jean-Paul Sartre. ${ }^{4}$ Indeed, as existential psychologist Rollo May puts it, the "central psychological endeavor of Kierkegaard may be summed up under the heading of the question he pursued relentlessly: "How can you become an individual?"5 May goes on to cite Kierkegaard's analysis of the fundamental cause of human despair - an individual's failure to establish authentic selfhood due to conforming to the external expectations of "The Crowd" - as "revolutionary" in its importance for the development of Western depth psychology generally and humanistic and existential psychology more specifically. ${ }^{6}$ 
Although diametrically opposed to a Kierkegaardian religious ontology, the implication of his famous slogan that "God is Dead," for Nietzsche, leads to the existential imperative to overcome a herd mentality of "bourgeois conformism" and follow one's own internal conscience to "become who you are." 7 A similar conception of authenticity is later picked up, most notably in the 20th century, by Sartre, who defines authenticity in contrast to bad faith - the failure to bear the responsibility for establishing one's own, authentic value system - where an authentic existence is one in which individuals take responsibility to create life meaning through their own unique, individual choices. Sartre's famous slogan that "existence precedes essence" provides a pithy summary of the existential agenda: since no a priori values exist, human beings must choose to live their lives according to their own internal dictates. Failure to do so is inauthentic, a state of being that, on the Kierkegaardian analysis, leads the individual to anxiety and despair. ${ }^{8}$

These existential philosophers had a major impact on a core group of mid-to-late 20th-century humanistic and existential psychologists, such as Karen Horney, Rollo May, Carl Rogers, and Irvin Yalom, who shared the beliefs of their philosophical forebears, rather than continuing the reigning Freudian psychoanalytic orthodoxy favored by their professional colleagues. ${ }^{9}$ The extension of these philosophical insights into the clinical setting and therapeutic encounter created a fundamentally new way to think about human functioning and well-being in the psychological realm. ${ }^{10}$ According to one contemporary researcher, these humanistic and existential psychologists, like those in the philosophical tradition from Aristotle to Nietzsche, "define the fundamental human good in terms of the principle of authenticity" and "emphasize the responsibility that individuals have to be true to themselves and the fulfillment of their unique potential for being." 11 This point is echoed in a recent empirical study conducted by Wood et al., who note that "in many mainstream counseling psychology perspectives, authenticity is seen as the most fundamental aspect of well-being. These researchers see authenticity not simply as an aspect or precursor to well-being, but rather as the very essence of well-being and healthy functioning." ${ }^{12}$

Indeed, in providing his own answer to Socrates' question, Carl Rogers drew explicitly from this tradition, writing that "The best way I can state this aim of life, as I see it coming to light in my relationship with my clients, is to use the words of Søren Kierkegaard - "to be that self which one truly is."13 Rogers describes that individuals in distress, as they grow in the therapeutic relationship, tend to move away from pleasing others: they "do not wish to be what they "ought" to be, whether that imperative is set by parents, or by the culture... the client moves toward being autonomous ...he becomes responsible for himself [and] decides what activities and ways of behaving have meaning." ${ }^{14}$ Similarly, Yalom argues that one achieves happiness by "plunging oneself into the "true" vocation of the human being, which, as Kierkegaard said, "is to will to be oneself" and cites approvingly the Hasidic rabbi, Susya, "who shortly before his death, said, "When I get to heaven they will not ask me, 'Why were you not Moses?' Instead, they will ask 'Why were you not Susya? Why did you not become what only you could become'?"15 May summarizes the position of the humanistic and existential therapist more generally, noting that "the dominant fear of men and women" has become "not to be accepted, to be thrown out of the group... One's own meaning becomes meaningless because it is borrowed from someone else's meaning." 16

In more recent years, the authenticity construct has begun to draw attention from contemporary empirical research psychologists in the social sciences. These researchers, drawing on the philosophical and existential psychological tradition, have sought to provide an empirical basis for the importance of authenticity for human well-being. 
For example, a 2003 study by the psychologist Michael H. Kernis, following an earlier paper by Deci and Ryan, posits that secure self-esteem is correlated with personal authenticity. ${ }^{17} \mathrm{He}$ writes that "high self-esteem develops when one's actions are self-determined and congruent with one's inner, core self, rather than a reflection of externally imposed or internally based demands. Activities are chosen and goals are undertaken because they are important to the individual."18 An authentic way of being is correlated with self-esteem and, in turn, increased feelings of personal worth that are not contingent on others' evaluations. For authentic individuals, esteem comes from within. ${ }^{19}$

In a later article, Kernis and Goldman present research evidence that indicates "authenticity relates to adaptive functioning" in several personal and interpersonal domains, such as "problem-focused coping strategies, mindfulness, positive role functioning, healthy aspects of self-concept structure, hedonic and eudemonic wellbeing, authentic goal pursuits, and low verbal defensiveness." ${ }^{20}$ A 2008 study by Wood et al. develops an "Authenticity Scale," which is used to "provide the first direct test of several theoretical models that view authenticity as integral to well-being." 21 Furthermore, Schlegel et al. present evidence in their 2009 study that authentic living leads to increased meaning in one's activities and in one's life more generally. ${ }^{22}$

This recent flood of empirical research grounding insights of the existential tradition in empirical reality gives us reason to seek out an application of the principle of authenticity in the educational context. For, as motivational researcher Edward Deci points out, "autonomy and authenticity, as opposed to control and alienation, are relevant in all aspects of life." ${ }^{23}$ Indeed, if authenticity is central to human happiness and the construction of meaning - as over two thousand years of inquiry into the concept suggests ${ }^{24}$-it would be more of a surprise than not if the construct did not play a significant role in human knowledge acquisition and the classroom context more generally.

\section{Authentic Learning: The Primary Task of the Teacher}

The same philosophical and psychological tradition that viewed the authentic life as central to human happiness also sought to establish a pedagogical approach facilitating the opportunity for students to bring their true selves to their schoolwork. Within the psychological tradition, Carl Rogers stands out as the theorist who has written the most about the application of humanistic psychological principles to the philosophy of education and learning. ${ }^{25}$ For Rogers, learning takes place on a continuum of meaning.

On one end of the spectrum is learning that has no personal meaning to the student-as in the rote learning of nonsense syllables. This kind of insignificant learning, for Rogers, is "likely to be forgotten quickly." ${ }^{26}$ Rogers theorizes that much of what counts as learning in the classroom bears a close resemblance to this kind of learning, since "nearly every student finds that large portions of his curriculum are for him, meaningless. Thus education becomes the futile attempt to learn material which has no personal meaning." ${ }^{27}$ In contrast, a key concept for Rogers is that of significant learning: that is, learning that has meaning and personal relevance to the

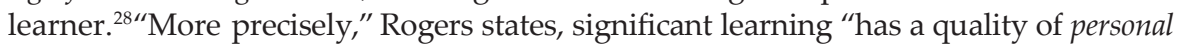
involvement ...even when the impetus or stimulus comes from the outside, the sense of discovery, of reaching out, of grasping and comprehending, comes from within... [The learner] knows whether it is meeting his need, whether it leads toward what he wants to know... The locus of evaluation, we might say, resides definitely in the learner." ${ }^{29}$ Significant learning takes place for the student, then, if and only if the student attaches some personal meaning to the subject of inquiry and wants to 
learn about the subject matter. In this sense, significant learning is synonymous with authentic learning: it is precisely the sense of personal meaning, sense of ownership, and caring about what is learned that establishes its relevance to the learner. ${ }^{30}$

The importance of the authenticity construct for learning also receives support in the recent empirical literature in educational psychology. For example, according to Assor, Kaplan, and Roth, teachers who support students' autonomy, specifically with regard to helping them "realize their personal goals and interests," are "particularly important in terms of their effects on feelings toward learning and cognitive and behavioral engagement in learning." ${ }^{31}$ Similarly, educational psychologist Erika A. Patall "highlights how useful providing choice can be to establishing a classroom environment and a teaching style that supports students' interest and enjoyment for school tasks." 32 This autonomy supportive behavior influences not only whether students "felt that their teachers listen, understand, encourage, care about and accept them" but also impacts more concrete learning outcomes, such as "higher GPA." 33

For this reason, autonomy supportive classroom activities have drawn considerable attention from the educational psychology literature, particularly for researchers interested in student motivation. Motivation is an important consideration for educators because the extent that students are motivated impacts the degree to which they learn. ${ }^{34}$ Student engagement has been demonstrated to contribute to student learning as measured by the grades students receive, their general knowledge acquisition, and intellectual development more broadly. ${ }^{35}$

Much of the literature on autonomy support in educational psychology has stressed the importance for student motivation of providing students with autonomous choices and autonomous control over their learning. ${ }^{36}$ Assor, Kaplan, and Roth are somewhat unique in the current literature, however, in recognizing the importance of providing students with choices that are deemed by the students to be authentic. In contrast to researchers who emphasize the importance of choice as such, they write that "being able to choose one's schoolwork may not be so important to students because none of the choices seems related to their personal goals or interests." ${ }^{37}$ It is not sufficient merely to give students choices, when those choices, in Rogerian terms, are not significant to the student. The choices, to create significant learning, must be authentically meaningful. Consequently, in a particularly striking passage, Assor, Kaplan, and Roth emphasize that

the primary task of the teacher is to try to understand their students' authentic interests and goals, and then help students to understand the connection between their personal goals and interests and schoolwork. In addition, teachers may also find or develop tasks that fit their students' interests. When students do not have clear personal interests and goals, teachers may assist them in developing such interests and goals." 38

Philosophically, this view represents a distinctively Rogerian approach to studentcentered learning. In a 1973 paper in the philosophy of education, Rogers - drawing on his therapeutic experience with his clients - states that if he were a teacher, one of his central questions would be: "Can I discover the interests of each individual and permit him or her to follow those interests?" ..."Can I be creative in putting them in touch with people, experiences, books - resources of all kinds - which stimulate their curiosity and feed their interests?"39

Thus, we see two main components coming out of Rogers's views of education:

1. Authentic Learning: The need for the facilitator of learning to find out students' interests in the classroom and allow them to pursue those interests. 
2. Providing Resources: The role of the facilitator of learning in providing students with the resources and materials necessary for them to learn about their interests.

The pedagogical need to discover students' interests is, for Rogers, due in part to his hypothesis that significant learning - authentic learning based on one's true interests-leads to more lasting learning, because that learning carries personal meaning for the learner. ${ }^{40}$ Rogers's insight is confirmed by recent empirical work. As Elliot et al. write, "[th]e interest students show in an activity or in an area of knowledge predicts how much they will attend to it and how well they process, comprehend, and remember it." 41 Thus, this type of authentic engagement is a particularly fruitful method for increasing student motivation, since, according to Edward Deci, "where the actions of students emanate from their true sense of self, so they are being authentic" - we should expect students to "embrace the activity with a sense of interest and commitment." 42

Put simply, increasing the level of authenticity a student feels in a particular task should increase the motivation of the student, because it makes the activity more meaningful. This increased engagement, in turn, should increase how much students learn. Since retention of information is one of the main goals of education, ${ }^{43}$ educators of all stripes have reason to be interested in the construct of authenticity, creating pedagogical experiences that will allow students to bring their true selves to their work.

\section{A Philosophy of Persons: Counselor Librarianship Revisited}

A central challenge for educators interested in authentic learning will be discovering students' interests. Rogers himself was aware of this difficulty. He wrote that

I may be over-confident... but I think... [i]f I genuinely wish to discover a student's interest I can do so. It might be through direct questions. It might be by creating a climate in which it is natural for interests to emerge. Although young people have been greatly deadened by their school experience, they do come to life in a healthy psychological atmosphere and are more than willing to share their desires. ${ }^{44}$

This approach to understanding students' needs - where an information and educational need is taken to be equivalent to understanding a student's individual interests-suggests a shift in perspective on the part of the educator, from viewing oneself as an expert transmitting information to others, to a student-centered focus where the educator inhabits a more facilitative role. For, the Rogerian model of authentic engagement requires not only understanding the nature and extent of a particular student's information need; this approach also requires understanding something about the student's needs as an individual person as well. It involves students sharing with the librarian who they really are.

Interestingly, a similar understanding of instructional pedagogy finds a historical precedent in academic libraries. Indeed, David K. Maxfield, in an article published in College $\mathcal{E}$ Research Libraries over half a century ago, argued that "[c]ollege librarians should give more careful attention to the individual needs of their undergraduate patrons" since "conventional reference work does not always place so much emphasis upon the library patron as an individual person as it does upon library materials and bibliographic techniques." ${ }^{45}$ This attitude bears a remarkable resemblance to what distinguished humanistic and existentialist psychologists such as Rogers and May from the Freudian psychoanalysts who came before them. The point is summarized by May, who wrote that " $[\mathrm{w}]$ hat distinguishes existential psychotherapy from other 
types of counseling is whether the human being is an object to be analyzed or a being to be understood. Any therapist is existential to the extent that... he is still able to relate to the patient as 'one existence communicating with another."'46

"Counselor Librarianship" - Maxfield's term for his distinctive approach - is thus grounded squarely in the humanistic and existential psychology popular during the time in which Maxfield worked in and wrote about libraries, an approach focused on authentic engagement with human beings. It requires librarians to understand students empathetically to help them incorporate their authentic selves into their schoolwork. "Being empathic," for Rogers, "involves a choice on the part of the therapist as to what she will pay attention to, namely, the inner world of the client as that individual perceives it." ${ }^{47}$ Empathic understanding of individuals as unique persons is therefore of central importance in the Rogerian counseling perspective; this focus will carry over into authentic engagement with library patrons as well. In this way, according to Maxfield, we can take into account the autonomy supportive conditions that "motivate thinking and learning and make them possible." 48

The need on the part of the library educator to approach standard informational interactions, such as the reference interview, as requiring effective communication between two persons is by now commonplace in academic librarianship. ${ }^{49}$ This was not always so. In one of the leading texts on reference librarianship, Reference and Information Services: An Introduction, edited by Bopp and Smith, writers Kern and Woodward note that the reference interview is where "library science becomes an art" precisely because it requires librarians to not only be good searchers, but effective at communicating with patrons as well. Placing the point in historical context, Kern and Woodward note that, as late as the mid-twentieth century, it was commonplace for patron interactions to be "focused more on the information needed to supply the user with resources" while ignoring "the interpersonal skills necessary to conduct the interview." This changed - at least in print-in 1954, "when David Maxfield applied interviewing principles from the counseling field to the reference interview, that acceptance, understanding, communication, and collaboration were identified as important to a successful reference interview. ${ }^{\prime 50}$ It is this kind of thinking that ultimately led to normative guidelines outlining best practices for interpersonal interactions during the reference interview, such as the RUSA Behavioral Guidelines for Conducting Reference Interactions, ${ }^{51}$ which stress the importance of certain personal qualities on the part of the librarian, in addition to the information skill set they possess as part of their professional expertise.

This reading of Maxfield, however, underemphasizes the depth, and ultimately, the radical nature, of the approach to understanding patrons, and library education more generally, underlying counselor librarianship. Maxfield's central insight was not merely that successful informational transactions require effective communication. Rather, Maxfield attempted to interject into librarianship a robust philosophy of persons aimed at understanding users as unique individuals with a distinctive set of needs and interests, because this approach not only helps them as human beings, but increases their learning as well. In this sense, Maxwell was remarkably prescient in his understanding of the information and educational needs of students. For the approach of authentically engaging with students' needs, which Maxfield based on the theories of philosophical counselors such as Rogers, now has a large body of empirical evidence to support its theoretical assumptions about human potential and learning. This literature did not exist, as it does now, for Maxfield to draw on. His approach to librarianship, instead, drew "upon the full resources of modern psychological theory and technique" available at the time..$^{52}$ This methodological principle, extended to the contemporary moment, has the potential to improve our 
practice as educators, through grounding reference and instruction librarianship in best practices deriving from the most current psychological literature in educational and counseling psychology.

Drawing on the work of information scientist Catherine Sheldrick Ross, we can then think of reference and instructional services as a kind of "information therapy" because, like a real therapeutic encounter in the clinical setting, it "helps a client understand their own needs." 53 It is important to note, however, that this approach need not require librarians to be therapists to patrons, and help them solve their personal problems. Rather, as Sarah Fine recently put the point in relation to reference, "[c]ounseling is above all else a philosophic stance" deriving from a "humanistic belief" in the potential of each person to be self-determining and to conduct one's life in an authentic manner. ${ }^{54}$ Librarians

give people the information they need, and with it the ability to gain more control and direction in their lives. The value of counseling theory and behavioral principles is to help us do what we do better... We become "counselors" neither from inclination nor training, but from the inescapable weight and intensity of our relationships. The only real question is often not whether the librarian should act as counselor, but whether the counseling is effective or not and whether it results in the right information for the right problem. ${ }^{55}$

There is a large body of literature-from philosophy, to counseling theory, to current research in educational psychology-suggesting that the right problem for librarians to focus on is facilitating the authenticity of their students. Exactly how to do this is a practical question of fundamental importance for library educators interested in increasing student learning.

\section{Applications to the Library Context}

Librarians are experts at providing resources and helping users find information. ${ }^{56} \mathrm{On}$ the Rogerian pedagogical model, this puts academic reference and instruction librarians in an ideal situation within the system of higher education for facilitating authentic learning. Rogers writes that,

a good facilitator of learning should spend up to $90 \%$ of his preparation time in making resources available to the young people with whom he or she works. To a large extent it is not necessary to teach them but they do need resources to feed their interests. It takes a great deal of imagination, thought, and work to provide such opportunities. ${ }^{57}$

For example, within academic libraries, librarians are often requested by faculty instructors to model database searching for their students. When this behavior is modeled within the context of a particular class research assignment-as much recent literature indicates is best for student learning ${ }^{58}$ - the librarian can demonstrate for students how to choose authentic topics based on one's individual interests. Instead of choosing a "generic" topic or keyword string to use as a sample search in the library database, the librarian may instead choose to model an authentic narrative, and walk students through the process, verbally and visually, of how they, the librarian, would have chosen a topic that interested them, relative to the constraints of their particular class assignment. ${ }^{59}$

The effectiveness of this method is supported by recent empirical research in the educational psychology literature. According to Elliot et al., educators should, 
"when possible, allow students to select topics that they are curious about" because this will give them "the freedom and the direction to explore for themselves." 60 And the best way to teach students to do this, according to Elliot et al., is to provide an effective model for students to follow. They write that a teacher ought to " $t]$ ell students the things you are curious about and model some of the resourceful behavior that curious people use to solve problems" for one's students. ${ }^{61}$ This modeling behavior, possible within the context of searching for information during one-shot library instruction, would provide a model for students on how to choose an authentic research question. The library instructor may suggest - in consultation with a faculty instructor - that students then develop research questions based on their own "authentic" interests. This approach would teach students to approach the research process in their academic work as an occasion to look up something that interests them, thereby modeling for students how more sophisticated researchers actually develop queries. ${ }^{62}$ As Booth, Colomb, and Williams note in The Craft of Research, a "research topic is an interest defined narrowly... Nothing contributes to the quality of your work more than your commitment to it. Start by listing two or three interests that you'd like to explore." ${ }^{63}$

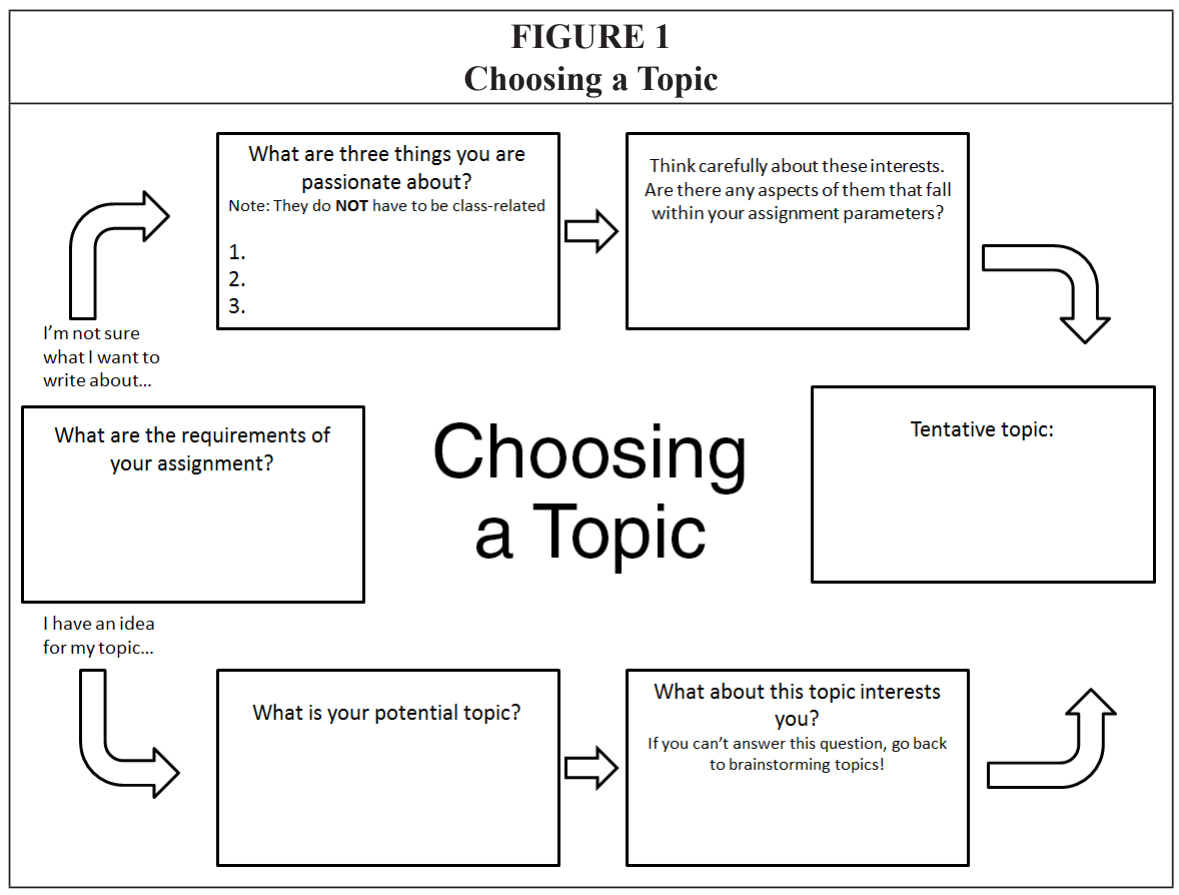

Figure 1 offers a helpful model for how students can go about choosing an authentic topic, either with librarian assistance, or on their own. ${ }^{64}$

It is also possible, during the reference interview, to encourage students to pursue authentic topical inquiries. Questions such as "what interests you about that topic?" are natural to ask when providing research assistance to students, and may prove useful for discovering students' authentic interests during reference transactions. This is especially the case during preliminary stages of the interview and when assisting students in the process of narrowing down a specific, researchable topic from a broad, more general interest. ${ }^{65}$ What is essential is to view the patron not 
as an information problem to be solved, but existentially. As David Maxfield writes, "when the inquirer is met as a unique individual, rather than as a mere consumer of bibliographical materials and techniques, his question may involve unexpected discoveries," including the "interests, goals, problems, backgrounds, and abilities of each individual student." 66 Therefore, simply adopting this philosophical stance toward the reference interview and librarian-patron interactions more generally - as an opportunity to understand who the patron is - may influence the librarian's ability to authentically facilitate the kind of research a student does.

Understanding a client's inner world to facilitate the patient's autonomy and authentic mode of life defines the task of the humanistic and existential psychotherapist. Similarly, for student-centered academic librarians, facilitating significant learning through authentic engagement with students will be central to reference and instruction. The counselor librarian aims to authentically engage with one's students, in the sense that an ideal informational transaction will be one in which the librarian and student meet as human beings. This requires the librarian to not only have knowledge of educational resources but to be a certain type of person, one who has a genuine desire to understand the inner world of another person. In doing so, the librarian assists students in the process of developing research questions that matter to them, using their informational skills to help students find information they care about. Thus, while the counselor librarian is fundamentally an information professional, he or she is also, in a very real sense, an existential counselor as well.

\section{Notes}

1. Bernard Williams, Ethics and the Limits of Philosophy (Cambridge, Mass.: Harvard University Press, 1985), 1; Michael H. Kernis and Brian M. Goldman, "A Multicomponent Conceptualization of Authenticity: Theory and Research," Advances in Experimental Social Psychology 38 (2006): 284; Rebecca J. Schlegel, Joshua A Hicks, Jamie Arndt, and Laura A. King, "Thine Own Self: True Self- Concept Accessibility and Meaning in Life," Journal of Personality and Social Psychology 96, no. 2 (2009): 473; Carolin Kreber and Monika Klampfleitner, "Construing the Meaning of Authenticity in University Teaching: Comparing Explicit to Implicit Theories," Journal of Constructivist Psychology 25 (2009): 34-35.

2. Kernis and Goldman, "A Multicomponent Conceptualization of Authenticity," 284; Schlegel, Hicks, Arndt, and King, "Thine Own Self," 473, 386.

3. Kernis and Goldman, "A Multicomponent Conceptualization of Authenticity," 285.

4. Kernis and Goldman, "A Multicomponent Conceptualization of Authenticity," 285; Schlegel, Hicks, Arndt, and King, "Thine Own Self," 473.

5. Rollo May, The Discovery of Being: Writings in Existential Psychology (New York: W.W. Norton \& Co., 1983), 69.

6. May, The Discovery of Being, 69-70. For Kierkegaard's analysis of "despair" as the failure to be oneself, see Kierkegaard, The Sickness Unto Death: A Christian Psychological Exposition for Upbuilding and Awakening (Princeton: Princeton University Press, 1980), 11-67.

7. May, The Discovery of Being, 79; cf. Friedrich Nietzsche, The Gay Science: With a Prelude in Rhymes and an Appendix of Songs (New York: Viking, 1980): §125, 270.

8. Jean-Paul Sartre, "The Humanism of Existentialism," in Essays in Existentialism, ed. W. Baskin (New York: Citadel Press), 31-62. See also Irvin Yalom, Existential Psychotherapy (New York: Basic Books, 1980), 218-76, 419-60.

9. Karen Horney, Neurosis and Human Growth: The Struggle toward Self-Realization (New York: W.W. Norton, 1991); Rollo May, Freedom and Destiny (New York: W.W. Norton, 1981) and The Discovery of Being; Carl Rogers, "'To Be That Self Which One Truly Is': A Therapist's View of Personal Goals," in On Becoming a Person: A Therapist's View of Psychotherapy (New York: Houghlin Mifflin), 163-82; Irvin Yalom, Existential Psychotherapy.

10. Alex M. Wood, P. Alex Linley, John Maltby, Michael Baliousis, and Stephen Joseph, "The Authentic Personality: A Theoretical and Empirical Conceptualization and the Development of the Authenticity Scale," Journal of Counseling Psychology 55, no. 3 (2008): 385; Schlegel, Hicks, Arndt, and King, "Thine Own Self," 473; Kernis and Goldman, "A Multicomponent 
Conceptualization of Authenticity," 285; Yalom, Existential Psychotherapy; Rogers, "To Be That Self Which One Truly Is"; Jennifer Grogan, Encountering America: Humanistic Psychology, Sixties Culture, $\mathcal{E}$ The Shaping of the Modern Self (New York: Harper Perennial, 2013).

11. Gordon Medlock, "The Evolving Ethic of Authenticity: From Humanistic to Positive Psychology," The Humanistic Psychologist 40, no. 1 (2012): 39.

12. Wood et al., "The Authentic Personality," 386.

13. Rogers, "To Be That Self Which One Truly Is," 86.

14. Rogers, "To Be That Self Which One Truly Is," 170-71; cf. Carl Rogers, "Ellen West and Loneliness," in A Way of Being (New York: Houghlin Mifflin), 164-80.

15. Yalom, Existential Psychotherapy, 285. See also Horney, Neurosis and Human Growth, 17-18.

16. May, The Discovery of Being, 21.

17. Michael H. Kernis, "Toward a Conception of Optimal Self-Esteem," Psychological Inquiry 14, no. 1 (2003): 1-26; Edward L. Deci and Richard M. Ryan, "Human Autonomy: The Basis for True Self- Esteem," in Efficacy, Agency, and Self-Esteem, ed. Michael H. Kernis (New York: Plenum Press, 1995), 31-50.

18. Kernis, "Toward a Conception of Optimal Self-Esteem," 8.

19. One common objection to the humanistic psychology movement is that its focus on self-esteem and personal fulfillment "encourages narcissism" (Grogan, Encountering America, 315; Christopher Lasch, The Culture of Narcissism [New York: W.W. Norton \& Co., 1979]; Jean Twenge, The Narcissism Epidemic [New York: Free Press, 2006]) and "spawns irresponsibility" (Edward L. Deci and Richard Flaste, Why We Do What We Do: Understanding Self-Motivation [New York: Penguin, 1996], 5). This objection, however, seems to misunderstand the psychological nature of narcissism. For, as Edward Deci writes, "although [these critics] might be right about a narcissistic preoccupation in this culture... it is not a preoccupation with the [authentic] self. On the contrary, narcissism involves desperately seeking affirmation from others. It entails an outward focus - a concern with what others think - and that focus takes people away from their true self. The narcissistic preoccupation results not from people's being aligned with the self but from their having lost contact with it. They adopt narcissistic values in a controlling society because they have not had the type of psychological nourishment they need to develop an integrated and healthy self. Narcissism is not the result of authenticity, it is their antithesis" (Why We Do What We Do, 6). For Rogers, one of the aspects of a "fully functioning human being" is precisely an "openness to and an acceptance of other individuals" (Rogers, "To Be That Self Which One Truly Is," 174; Rogers, "Empathetic: An Unappreciated Way of Being," in A Way of Being: 137-65). Furthermore, as Grogan notes, these criticisms of the humanistic psychology movement are more apt of the "pop" humanistic movement that resulted from the work of the humanists and the 1960s more generally, than the work and research of the humanists themselves. Indeed, the narcissism and sense of entitlement resulting from this movement is more likely the result of false praise - telling children that what they do is great even when this is not the case-rather than true, autonomy supportive parenting. On this point, see Deci, Why We Do What We Do, chapter 9; Carol Dweck, Mindset: The New Psychology of Success (New York: Ballantine Books, 2006). See also E. Brummelman, S. Thomaes, G. Overbeek, B. Orobio de Castro, M.A. van den Hout, and B.J. Bushman, “On Feeding Those Hungry for Praise: Person Praise Backfires in Children with Low Self-Esteem," Journal of Experimental Psychology (2013). Note, too, that existentialists such as Rogers and Yalom defend a radical ethic of personal responsibility where an authentic "individual becomes responsible for himself" (Rogers, "To Be That Self Which One Truly Is," 171) and where the avoidance of personal responsibility and autonomous behavior are fundamental aspects of maladjustment (Yalom, Existential Psychotherapy, 227-30). Although, for Yalom, "one must create one's own meaning," altruism - "leaving the world a better place to live in, serving others, participation in charity ... - these activities are right and good and have provided life meaning for many humans" (Existential Psychotherapy, 431). I thank an anonymous reviewer of this journal for raising this issue.

20. Kernis and Goldman, "A Multicomponent Conceptualization of Authenticity: Theory and Research,"34.

21. Wood, Linley, Maltby, Baliousis, and Joseph, "The Authentic Personality," 385.

22. Schlegel, Hicks, Arndt, and King, "Thine Own Self," 485.

23. Deci and Flaste, Why We Do What We Do, 2.

24. Although this article is focused on the Western tradition in both philosophy and psychology, it is important to note that similar notions of authenticity are, in fact, found in the history of Eastern thought and religious practice. For example, the Bhagavad Gita, the sacred ancient Hindu text, presents the path of Karma Yoga as one of four possible routes to religious enlightenment, through a life of practical action and "selfless service" (Patrick S. Bresnan, Awakening: An Introduction to the History of Eastern Thought [Upper Saddle River, N.J.: Prentice Hall, 1999], 73). On this path, spiritual liberation and awakening is attained by egoless activity that 
also benefits others. "The only requirement," writes Bresnan, "is that it be of some genuine value to the community, and that, all in all, the person loves the work. This is essential because it is only love that dissolves the grip of ego. If one does not love the work, then it becomes merely a means to an end" (74). Thus, on the path of Karma Yoga, following one's passion is the "path of right action" to selfless service: "This is what happens naturally when you work at something you love to do. An artist absorbed in a painting, or a scientist focused on a research project... all of these are examples of selfless action. The key point is that one forgets himself, temporarily transcends his ego-self, by becoming absorbed in a loved activity" (74). Recent work in positive psychology on the nature of the "flow" state draws from this tradition; Mihaly Csikszentmihalyi's book Flow: The Psychology of Optimal Experience (Harper Perennial: New York, 1990) continues to be the seminal text in this literature. Additionally, recent empirical literature supports the claim that the path of Karma Yoga leads to increased empathy and other-regarding behavior. On this point, see: Zubin R. Mulla and Venkat R. Krishnan, "Karma-Yoga: Construct Validation Using Value Systems and Emotional Intelligence," South Asian Journal of Management 14, no. 4 (Oct. 2007): 116-37; and Zubin R. Mulla and Venkat R. Krishnan, "Karma-yoga: The Indian Model of Moral Development," Journal of Business Ethics (Aug. 2013): PsycINFO, EBSCOhost [accessed 4 October 2013].

25. Indeed, Rogers devoted several essays and a book collection to discussing the impact of his client- centered therapy on education. See, for example, Carl R. Rogers, Freedom to Learn (Columbus, Ohio: Charles E. Merrill Publishing Company, 1969); Carl Rogers, “Questions I Would Ask Myself If I Were a Teacher," Education 95, no. 2 (1974): 134-39. See also Caroline Heim, "Tutorial Facilitation in the Humanities Based on the Tenets of Carl Rogers," Higher Education 63 (2012): 289-98.

26. Rogers, Freedom to Learn, 3.

27. Ibid., 4.

28. Ibid., 3-4; Cecil Patterson, Foundations for a Theory of Instructional and Educational Psychology (New York: Harper \& Row, 1977), 301.

29. Rogers, Freedom to Learn, 5 (italics in original).

30. Patterson, Foundations for a Theory of Instructional and Educational Psychology, 301-02.

31. Assor, Avi, Haya Kaplan, and Guy Roth. "Choice is Good, but Relevance is Excellent: Autonomy-Enhancing and Suppressing Teacher Behaviors Predicting Students' Engagement in Schoolwork." British Journal Of Educational Psychology 72, no. 2 (June 2002): 272.

32. Erika A. Patall, Harris Cooper, and Susan R. Wynn, "The Effectiveness and Relative Importance of Choice in the Classroom," Journal of Educational Psychology 102, no. 4 (2010): 912.

33. Ibid.

34. Ernest T. Pascarella and Patrick T. Terenzini, How College Affects Students: Findings and Insights from Twenty Years of Research (San Francisco: Jossey-Bass, 1991), 32; Elizabeth F. Barkley, Student Engagement Techniques: A Handbook for College Faculty (San Francisco: John Wiley \& Sons, 2010), 9; Edward L. Deci, Hyungshim Jang, and John Marshall Reeve, "Engaging Students in Learning Activities: It Is Not Autonomy Support or Structure but Autonomy Support and Structure," Journal of Educational Psychology 102, no. 3 (2010): 588-600.

35. Deci et al., "Engaging Students in Learning Activities," 588; Educational Psychology: Effective Teaching, Effective Learning, 3rd ed., eds. Stephen N. Elliot, Thomas Kratochwill, and Joan Littlefield Cook (Boston: McGraw Hill, 2000), 349.

36. For an overview, see Dale H. Schunk and Barry J. Zimmerman, "Competence and Control Beliefs: Distinguishing the Means and Ends," in The Handbook of Educational Psychology (New York: Routledge, 2009): 349-367; Stefanou, Candice R., et al. "Supporting Autonomy in the Classroom: Ways Teachers Encourage Decision Making and Ownership." Educational Psychologist 39, no. 2 (Spring 2004): 97-110.

37. Assor, Kaplan, and Roth, "Choice Is Good, but Relevance Is Excellent: Enhancing and Suppressing Teacher Behaviors Predicting Students' Engagement in Schoolwork," 273.

38. Ibid.

39. Rogers, "Questions I Would Ask Myself If I Were a Teacher," 6.

40. Rogers, Freedom to Learn, 5.

41. Elliot et al., Educational Psychology, 349.

42. Deci and Flaste, Why We Do What We Do, 2-4.

43. Richard E. Mayer and Merlin C. Wittrock, "Problem Solving," in The Handbook of Educational Psychology (New York: Routledge, 2006), 349.

44. Rogers, "Questions I Would Ask Myself If I Were a Teacher," 3.

45. David K. Maxfield, "Counselor Librarianship at U.I.C," College and Research Libraries 15 (1954): 162.

46. May, The Discovery of Being, 158.

47. Carl Rogers, Carl Rogers on Personal Power (New York: Delacorte Press, 1977), 11. 
48. Maxfield, "Counselor Librarianship at U.I.C.," 163.

49. M. Kathleen Kern and Beth S. Woodard, "The Reference Interview," in Reference and Information Services: An Introduction, eds. Bopp and Smith (Santa Barbara, Calif.: Libraries Unlimited, 2011), 57-94.

50. Kern and Woodward, "The Reference Interview," 57.

51. Reference and User Services Association: A Division of the American Library Association, "Guidelines for Behavioral Performance of Reference and Information Service Providers," revised May 28, 2013, http://www.ala.org/rusa/resources/guidelines/guidelinesbehavioral.

52. David K. Maxfield, “Counseling Librarianship: A New Departure," University of Illinois Library School, Occasional Papers: No. 38, March 1954: 16.

53. Catherine Sheldrick Ross, "The Reference Interview: Why It Needs to Be Used in Every (Well, Almost Every) Reference Transaction," Reference E User Services Quarterly 43, no. 1 (Fall 2003): 38 .

54. Sara Fine, “Librarians and the Art of Helping," The Reference Librarian 59 (1997): 80.

55. Fine, "Librarians and the Art of Helping," 90-91.

56. Fine, "Librarians and the Art of Helping," 91

57. Rogers, "Questions I Would Ask Myself," 4.

58. See, for instance, Yvonne Nalani Meulemans and Allison Carr, "Not at Your Service: Building Genuine Faculty- Librarian Partnerships," Reference Services Review 41, no. 1 (2012): 80-90.

59. It is also possible to conduct a more general instruction session around the theme of developing a research question that interests the student. The author recently led a joint workshop sponsored by the CSU Chico Information Literacy Program and the Student Learning Center about how to choose an "authentic" research topic, using the example of the author's interest in the rapper Drake as an example. See: http://rce.csuchico.edu/online/workshops/student-learning.

60. Elliot et al., Educational Psychology, 349.

61. Ibid.

62. Preliminary research suggests that this approach increases student engagement and retention of information literacy concepts in students for whom authentic topic selection is modeled over similarly situated students given more "generic" database instruction. See Kevin Michael Klipfel, "Authentic Engagement: Assessing the Effects of Authenticity on Student Engagement and Information Literacy in Academic Library Instruction" (master's paper, The University of North Carolina at Chapel Hill, 2013).

63. Wayne C. Booth, Gregory G. Colomb, and Joseph M. Williams, The Craft of Research, 2nd ed. (Chicago: The University of Chicago Press, 2003), 40.

64. Chart created by Dani Brecher, Instructional Design and Technology Librarian, Claremont Colleges Library, based on research in Kevin Michael Klipfel, "Authentic Engagement."

65. This strategy should be effective both in person and during online chat reference. For applications of Rogerian pedagogy to the online environment, see Christopher T. Miller, "Enhancing Web-Based Instruction Using a Person-Centered Model of Instruction," Quarterly Review of Distance Education 8 (2007): 25-34.

66. Maxfield, "Counselor Librarianship at U.I.C.," 164. 